\title{
TINJAUAN KINETIKA PROSES EKSITASI PADA PENENTUAN UNSUR DENGAN SPEKTROGRAFI EMISI
}

\author{
NOOR ANIS KUNDARI", SAHAT SIMBOLON*", DAN WIWIEN ANDRIYANTI ** \\ "Sekolah Tinggi Teknologi Nuklir \\ Badan Tenaga Nuklir Nasional - BATAN \\ JL. Babarsari Kotak Pos 1008, Yogyakarta 55010 \\ ". Pusat Teknologi Akselerator dan Proses Bahan-BATAN \\ Badan Tenaga Nuklir Nasional - BATAN \\ JL.Babarsari Kotak Pos 1008, Yogyakarta 55010
}

\begin{abstract}
Abstrak
Penelitian ini bertujuan untuk menentukan persamaan kecepatan reaksi yang terjadi pada proses eksitasi dalam analisis boron dan kadmium dengan spektrografi emisi. Hal ini dimaksudkan agar diperoleh suatu tambahan informasi ilmiah yang terjadi pada proses eksitasi, sehingga dapat dimanfaatkan untuk memperbaiki teknik analisis menggunakan spekrografi emisi. Data yang dievaluasi adalah analisis boron dan kadmium dalam $\mathrm{U}_{3} \mathrm{O}_{8}$ dengan pengemban sulingan campuran $\mathrm{Ga}_{2} \mathrm{O}_{3}, \mathrm{LiF}$, dan $\mathrm{AgCl}$. Sebelum dikumpulkan data untuk keperluan penentuan persamaan kecepatan reaksi, dilakukan optimasi konsentrasi pengemban sulingan. Konsentrasi pengemban sulingan terbaik digunakan untuk proses analisis. Dari hubungan intensitas dengan konsentrasi pengemban didapatkan konsentrasi pengemban yang paling baik adalah $5 \%$. Hubungan kadar boron dan kadmium yang didapatkan saat eksitasi yang divariasi waktu digunakan untuk menghitung konsentrasi sehingga diperoleh hubungan konsentrasi dengan waktu. Dengan metode diferensial diperoleh diperoleh bahwa reaksi itu mengikuti orde satu. Selanjutnya data diolah dengan menggunakan metode integral, sehingga didapat untuk persamaaan kecepatan reaksi boron yaitu $-\mathrm{r}_{\mathrm{B}}=-\frac{\mathrm{dC}_{\mathrm{B}}}{\mathrm{dt}}=0,066 \mathrm{C}_{\mathrm{A}}{ }^{1} \frac{\mathrm{mg}}{\mathrm{g} \cdot \mathrm{s}}$ dan untuk kadmium yaitu:

$-\mathrm{r}_{\mathrm{Cd}}=-\frac{\mathrm{dC}_{\mathrm{Cd}}}{\mathrm{dt}}=0,068 \mathrm{C}_{\mathrm{A}}{ }^{1} \frac{\mathrm{mg}}{\mathrm{g} \cdot \mathrm{s}}$.
\end{abstract}

Kata kunci: spektrografi emisi, persamaan kecepatan reaksi, eksitasi

\section{Abstract}

KINETICS STUDY OF EXITATION PROCESS ON DETERMINATION OF UNSURE BY EMISSION SPECTROGRAPHIC METHODE. The research aim was to search the rate of reaction equation occurred in the excitation process during the determination of boron and cadmium impurities in $\mathrm{U}_{3} \mathrm{O}_{8}$ by emission spectrographic methode. It was intended to obtain additional information that could be used to improve the analysis method using emission spectrographic, especially on the excitation process. From the intensity relationship with the carrier concentration, the best carrier concentration obtained was $5 \%$. The relationship between boron and cadmium contained obtained during the excitation being varied with time is used to count the concentration so that a relationship between the concentration and time was obtained. By differential method, the 
relationship between the rate and concentration was obtained that these reactions followed

first orde. This first orde could evaluated with integral methode. The rate of reaction equations obtained for boron and cadmium respectively were $-\mathrm{r}_{\mathrm{B}}=-\frac{\mathrm{dC}_{\mathrm{B}}}{\mathrm{dt}}=0,066 \mathrm{C}_{\mathrm{A}}{ }^{1} \frac{\mathrm{mg}}{\mathrm{g} \cdot \mathrm{s}}$ and $-\mathrm{r}_{\mathrm{Cd}}=-\frac{\mathrm{dC}_{\mathrm{Cd}}}{\mathrm{dt}}=0,068 \mathrm{C}_{\mathrm{A}}{ }^{1} \frac{\mathrm{mg}}{\mathrm{g} \cdot \mathrm{s}}$.

Keywords: emmission spectrographic, reaction rate equation, exitation.

\section{PENDAHULUAN}

Penelitian ini bertujuan untuk memperoleh persamaan kecepatan reaksi proses eksitasi pada penentuan unsur dengan spektrografi emisi. Data yang digunakan adalah data analisis unsur takmurnian boron dan kadmium dalam $\mathrm{U}_{3} \mathrm{O}_{8}$. Manfaat yang dapat diperoleh dari penelitian ini adalah menambah informasi ilmiah terkait dengan kinetika kimia pada proses eksitasi dalam analisis unsur menggunakan spektrografi emisi. Informasi ilmiah ini dapat dimanfaatkan untuk memperbaiki metode analisis dengan cara spektrografi emisi khususnya pada proses eksitasi. Pada proses eksitasi diharapkan semua unsur yang akan dianalisis dapat tereksitasi sehingga diperoleh hasil yang sesuai dengan yang ada dalam cuplikan. Oleh karena itu diperlukan energi dan waktu yang memadai. Pada umumnya hal ini dilakukan dengan melakukan variasi waktu eksitasi sebelum analisis yang sebenarnya. Pada makalah ini data variasi waktu itu dievaluasi sehingga diperoleh persamaan kinetika. Jika persamaan kinetika sudah diperoleh dapat digunakan untuk keperluan menghitung waktu eksitasi yang optimum sehingga pelaksanaan analisis serupa selanjutnya diharapkan dapat lebih baik dan efisien.

Spektrografi emisi adalah alat untuk analisis kimia yang berkembang sejak ditemukannya spektra dari nyala api oleh Bunsen dan Kirchoff. Spektrografi emisi merupakan alat yang digunakan untuk menentukan banyak unsur dalam suatu senyawa, baik padatan maupun larutan berdasarkan panjang gelombang dan intensitas garis-garis spektra dari unsur-unsur yang bersangkutan. Garis-garis spektra tersebut dapat terjadi karena adanya pancaran sinar (dari panjang gelombang tertentu) akibat perpindahan elektron dari tingkat tenaga yang lebih tinggi ke tingkat tenaga yang lebih rendah. Garis spektra pada panjang gelombang tertentu adalah karakteristik untuk setiap unsur. Metode ini bersifat spesifik, peka, dan dapat menganalisis secara beberapa unsur secara serentak, baik padatan maupun larutan berdasarkan panjang gelombang dan intensitas garis-garis spektra dari unsur-unsur yang bersangkutan ${ }^{[1]}$.

Prinsip dasar metode analisis spektrografi emisi adalah apabila suatu unsur diletakkan dalam sumber energi pengeksitasi, maka elektron yang terdapat pada orbital paling luar akan tereksitasi ke tingkat energi elektron yang lebih tinggi. Keadaan tereksitasi merupakan keadaan yang tidak stabil dan secepatnya akan 
kembali ke tingkat energi elektron semula sambil memancarkan sinar yang mempunyai panjang gelombang karakteristik untuk setiap unsur yang berbeda. Gambar 1 menunjukkan diagram proses analisis spektrografi emisi.

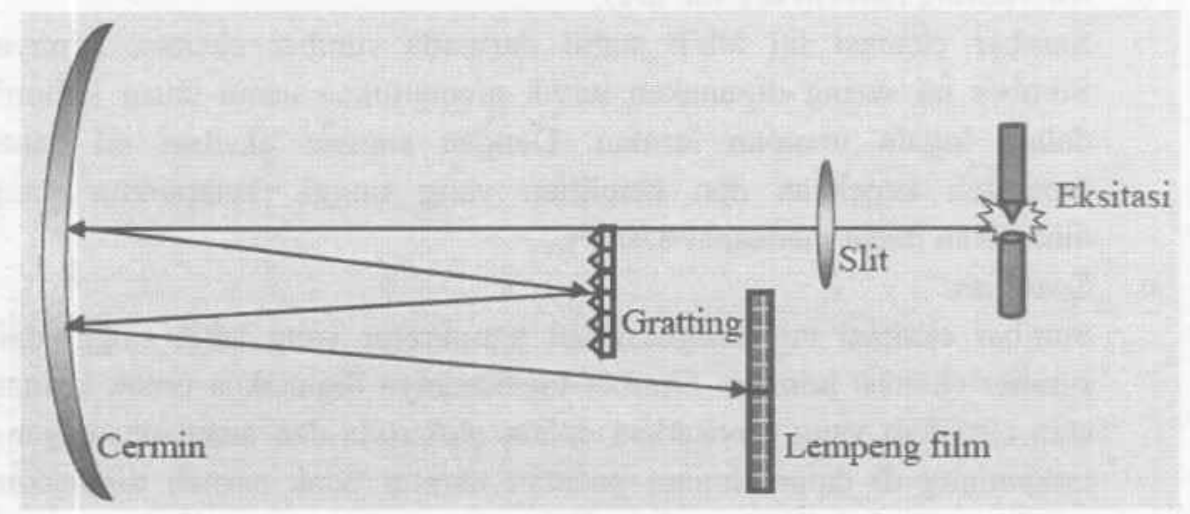

Gambar 1. Diagram Proses Eksitasi Alat Analisis Spektrografi Emisi

Pancaran sinar ini jika dibiarkan melalui suatu alat pendispersi seperti prisma melewati cermin maka akan diperoleh suatu spektrum emisi yang ditangkap oleh film atau pelat foto yang dipasang di belakang prisma. Intensitas sinar yang dipancarkan oleh atom unsur tersebut menyebabkan pelat film menjadi hitam pada tempat-tempat tertentu yang terkena sinar tersebut. Untuk bisa mengetahui bentuk spektrumnya, film atau pelat foto harus dicuci terlebih dahulu. Pencucian film atau pelat foto ini dilakukan di kamar gelap. Instrumentasi alat spektrografi emisi secara garis besar terdiri atas empat komponen utama, sebagai berikut ${ }^{[2,3]}$.

\section{Sumber Eksitasi}

Sumber eksitasi yang digunakan dalam spektrografi emisi berfungsi untuk mengubah bentuk cuplikan menjadi bentuk uap gas dan selanjutnya mengeksitasi atom sehingga terjadi transisi elektron di dalam atom tersebut. Tenaga yang digunakan untuk eksitasi berasal dari :

1. Nyala api (flame source)

Temperatur yang dihasilkan oleh sumber eksitasi nyala api ini antara suhu $1000^{\circ} \mathrm{C}-3000^{\circ} \mathrm{C}$.

2. Tenaga listrik (elektric arc source)

Temperatur yang dihasilkan oleh sumber eksitasi busur listrik ini antara suhu $3000{ }^{\circ} \mathrm{C}-8000{ }^{\circ} \mathrm{C}$. Berdasarkan rangkaian elektronik, sumber eksitasi tenaga listrik dibedakan menjadi :

a. Direct current arc (dc arc)

Sumber eksitasi ini paling sering digunakan karena mempunyai kepekaan tinggi dibandingkan dengan sumber eksitasi lainnya dan dapat digunakan untuk segala bentuk cuplikan. Sumber eksitasi ini cocok untuk menentukan unsur-unsur kelumit (trace elements), tetapi 
tidak begitu menguntungkan untuk menentukan unsur makro (mayor elements) karena adanya absorpsi diri (self absorbtion) spektra.

b. Alternating current arc (ac arc).

Sumber eksitasi ini lebih stabil daripada sumber eksitasi lainnya. Sumber ini sering digunakan untuk menentukan unsur-unsur kelumit dalam logam maupun larutan. Dengan sumber eksitasi ini dapat diperoleh kepekaan dan ketelitian yang tinggi. Temperatur yang dihasilkan dapat mencapai $8500{ }^{\circ} \mathrm{C}$.

c. Spark arc.

Sumber eksitasi ini menghasilkan temperatur yang lebih tinggi dari sumber eksitasi lainnya. Sumber ini biasanya digunakan untuk larutan atau cuplikan yang dipekatkan dalam elektroda dan unsur-unsur yang terkandung di dalam logam padatan namun tidak pernah digunakan untuk cuplikan dalam bentuk serbuk.

d. Sumber eksitasi plasma.

Sumber eksitasi ini dapat menghasilkan tenaga panas hingga mencapai suhu $\pm 20.000{ }^{\circ} \mathrm{C}$, dan memiliki kepekaan dan ketelitian yang tinggi. Umumnya cuplikan yang dianalisis berbentuk larutan.

e. Sumber eksitasi laser

Laser dapat digunakan untuk mengeksitasi atom dari unsur yang terkandung di dalam cuplikan. Dengan metode ini jumlah cuplikan yang dianalisis hanya berbentuk bintik noda (spot), biasanya berukuran $\pm 50 \mu \mathrm{m}$.

Pada proses eksitasi diharapkan semua atom yang akan dianalisis dalam cuplikan dapat tereksitasi. Untuk keperluan ini diperlukan waktu.

\section{Media Pengurai Sinar}

Setiap spektrograf dilengkapi dengan media pengurai sinar radiasi. Dalam spektrografi emisi ada dua macam pengurai sinar, yaitu prisma dan kisi difraksi (grating). Kedua pengurai tersebut berfungsi untuk menguraikan berkas sinar yang dihasilkan pada proses eksitasi menjadi garis-garis spektra yang terpisah. Prisma biasanya dibuat dari gelas kuarsa atau kristal sedangkan kisi difraksi dibuat dari logam (biasanya perak) atau gelas yang pada permukaannya dibuat lekukan (grooves), dipoles atau dilapis dengan lapisan tipis alumunium.

\section{Celah (Slit) dan Diafragma}

Sebelum sinar radiasi menuju sistem optik, terlebih dahulu dilewatkan melalui celah dan atau diafragma. Fungsi celah ini untuk mengatur lebar spektra dan diafragma berfungsi untuk mengatur tinggi garis spektra. Alat ini secara mekanik dapat diatur dengan teliti dan hati-hati. 


\section{Elektrode}

Dalam analisis spektrografi emisi, sering digunakan elektrode grafit kemurnian tinggi sebagai wadah cuplikan. Untuk keperluan tertentu adakalanya digunakan elektrode logam murni, seperti : tembaga $(\mathrm{Cu})$, perak $(\mathrm{Ag})$, alumunium $(\mathrm{Al})$, dan platina (Pt).

Gambar 2 menunjukkan skema sistem optik dan elektroda dalam alat spektrografi emisi.

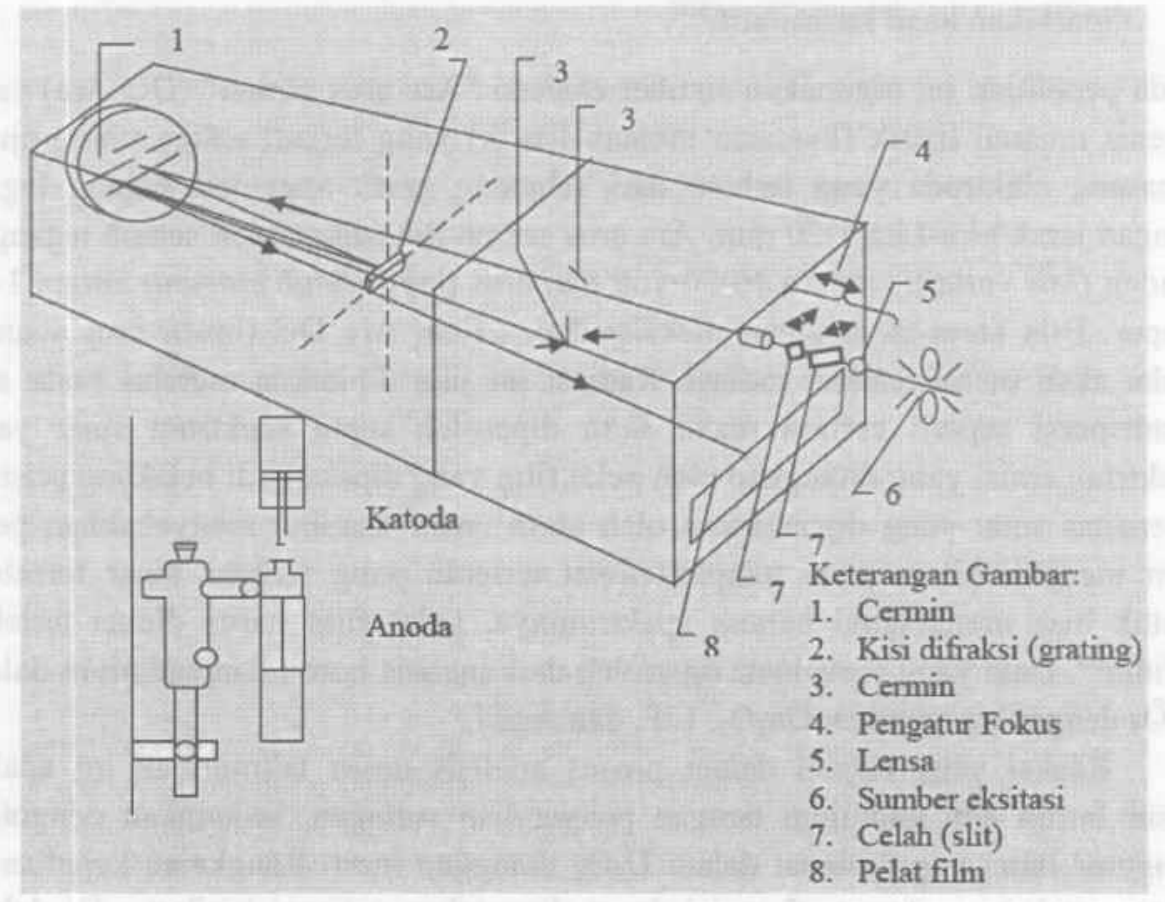

\section{Gambar 2. Skema Optik Spektrografi Emisi}

Spektrografi emisi dapat diterapkan untuk pengujian ketidakmurnian pada suatu logam, analisis abu zat-zat organik dan bahan lain, misalnya air alam dan deteksi kontaminan dalam makanan. Keuntungan utama metode spektrografi emisi untuk analisis adalah sebagai berikut :

a. Prosedur spesifik untuk unsur yang akan ditetapkan, meskipun kadangkadang timbul kesulitan bila garis unsur lain tumpang tindih dengan garis unsur yang dianalisis.

b. Menghemat waktu karena dapat dilakukan tanpa pengolahan pendahuluan apapun. Kebanyakan logam dan beberapa bukan logam, misalnya fosforus, silikon, arsen, dan boron dapat ditentukan.

c. Dapat diperoleh rekaman permanen pada lempeng film.

d. Pemisahan yang sukar dan berkepanjangan dengan metode kimia dapat dihindari. 
Kerugian yang biasa terjadi pada metode spektrografi emisi adalah sebagai berikut.

a. Penggunaan yang berhasil menuntut pengalaman yang luas, baik dalam operasi alat maupun dalam membaca dan menafsirkan spektra.

b. Untuk analisis kuantitatif diperlukan standar (biasanya komposisinya serupa dengan komposisi bahan yang akan dianalisis), oleh karena itu contohcontoh yang tidak dikenal akan memberikan masalah relatif sulit bila diperlukan hasil kuantitatif ${ }^{[4,5]}$.

Pada penelitian ini digunakan sumber eksitasi "Arc arus searah" (DC Arc) yaitu sejenis muatan listrik (loncatan muatan listrik) yang terjadi antara ujung-ujung sepasang elektroda yang terbuat dari sebatang grafit atau dari batang logam dengan jarak kira-kira 1-20 mm. Arc arus searah dihasilkan oleh selisih tegangan rendah (low voltage) antara 10-50 volt dan arus tinggi (high current) antara 1-35 amper. Bila atom-atom unsur dieksitasikan dalam Arc DC (busur arus searah) maka akan memancarkan radiasi. Radiasi ini jika dibiarkan melalui suatu alat pendispersi seperti cermin maka akan diperoleh suatu spektrum sinar yaitu spektrum emisi yang ditangkap oleh pelat film yang dipasang di belakang prisma. Intensitas sinar yang dipancarkan oleh atom unsur tersebut menyebabkan pelat film menjadi hitam pada tempat-tempat tertentu yang terkena sinar tersebut. Untuk bisa mengetahui bentuk spektrumnya, pelat film harus dicuci terlebih dahulu $^{[2]}$. Data yang dievaluasi diperoleh dari analisis boron dan cadmium dalam $\mathrm{U}_{3} \mathrm{O}_{8}$ dengan pengemban $\mathrm{Ga}_{2} \mathrm{O}_{3}, \mathrm{LiF}$, dan $\mathrm{AgCl}$.

Reaksi yang terjadi dalam proses analisis unsur takmurnian ini adalah unsur boron dan kadmium dengan pengemban sulingan, sedangkan pengotorpengotor lain yang terdapat dalam $\mathrm{U}_{3} \mathrm{O}_{8}$ dianggap inert. Rangkaian kejadian di dalam analisis spektrografi emisi dapat dinyatakan sebagai berikut : Di dalam sistem eksitasi terjadi transisi atom-atom dalam cuplikan ke keadaan fase gas $\mathrm{C} \rightarrow \mathrm{N}$; transisi sejumlah tertentu atom-atom dari keadaan gas ke keadaan tereksitasi $\mathrm{N} \rightarrow \mathrm{N}^{*}$; perubahan tenaga eksitasi menjadi radiasi garis spektra $\mathrm{N}^{*} \rightarrow \quad \mathrm{I}$; pengubahan radiasi garis spektra menjadi besaran yang dapat diukur I

$\rightarrow$ T. Secara singkat, rangkaian kejadian di dalam analisis spektrografi emisi dapat dinyatakan sebagai berikut.

$$
\mathrm{C} \rightarrow \mathrm{N} \rightarrow \mathrm{N}^{*} \rightarrow \mathrm{I} \rightarrow \mathrm{T}
$$

Dari uraian itu persamaan yang terjadi pada proses eksitasi adalah:

$$
\mathrm{N} \rightarrow \mathrm{N}^{*}
$$

Dalam eksitasi ini proses elementer yang terjadi adalah tumbukan termal antara elektron dengan partikel-partikel berat di dalam atom, ion, dan molekul dengan keadaan gas. Kecepatan reaksi eksitasi adalah sebagai berikut ${ }^{[2,3]}$. 


$$
\frac{d N_{1}}{d t}=N_{0} N_{e}\left(\sigma_{01} v\right)-N_{1} N_{e}\left(\sigma_{10}^{\prime} v v^{\prime}\right)-A_{10}
$$

dengan:

$\mathrm{N}_{0} \quad=$ cacah atom pada keadaan tak tereksitasi

$\mathrm{N}_{1} \quad=$ cacah atom pada keadaan tereksitasi

$\mathrm{N}_{\mathrm{e}} \quad=$ jumlah elektron yang mengadakan tumbukan

Termal I = cacah/jumlah eksitasi disebabkan oleh tumbukan elektron yang menyebabkan transisi atom dari keadaan satu (tereksitasi)

Termal II = cacah/jumlah redaman yang menyebabkan transisi atom dari keadaan satu (tereksitasi) ke keadaan 0

Termal III $=$ tranmisi atom dari keadaan 1 ke keadaan 0 disebabkan oleh emisi spontan

$v \quad=$ kecepatan elektron pengeksitasi

$v=$ kecepatan elektron setelah tumbukan

$\sigma_{01} \quad=$ penampang tumbukan eksitasi

$\sigma_{10}^{\prime} \quad=$ penampang tumbukan de-eksitasi

$\mathrm{A}_{10}=$ koefisien einstein

Di dalam plasma spark dan arc terdapat distribusi elektron dengan parameter $T_{e}$ yang merupakan temperatur elektron dalam plasma. Dalam keadaaan stasioner, perubahan kecepatan eksitasi $\mathrm{dN}_{1} / \mathrm{dt}=0$ sehingga Persamaan 2 menjadi :

$$
N_{1}=N_{0} \frac{N_{e}\left(\sigma_{01} v\right)}{N_{e}\left(\sigma_{10}^{\prime} v^{\prime}\right)+A_{10}}
$$

Hubungan $\sigma_{01}$ dan $\sigma_{10}^{\prime}$ dapat dinyatakan dengan persamaan sebagai berikut :

$$
\frac{\left(\sigma_{01} v\right)}{\left(\sigma_{10}^{\prime} v\right)}=\frac{g r_{1}}{g r_{0}} e^{-E / k T}
$$

dengan:

$\mathrm{gr}_{1}=$ berat statistik atom pada keadaan 1 (tereksitasi)

$\mathrm{gr}_{0}=$ berat statistik atom pada keadaan 0 (tak tereksitasi)

$\mathrm{E}_{\mathrm{r}} \quad=$ tenaga eksitasi (satuan elektron volt)

$\mathrm{K}=$ tetapan 
Perbandingan kecepatan eksitasi dan deeksitasi dinyatakan dengan $\mathrm{R}$ sebagai berikut.

$$
R=\frac{A_{10}}{\left(\sigma_{10}^{\prime} v\right)}
$$

Dengan memperhatikan Persamaan 3, 4, dan 5, maka jumlah atom tereksitasi per satuan volum adalah $\mathrm{N}_{1}^{\prime}$ yang bisa dinyatakan dengan persamaan sebagai berikut.

$$
\mathrm{N}_{1}^{*}=\mathrm{N}_{0} \frac{1}{1+\mathrm{R} / \mathrm{N}_{\mathrm{e}}} \frac{\mathrm{gr}_{1}}{\mathrm{gr}_{0}} \mathrm{e}^{-\mathrm{E}_{\mathrm{r}} / \mathrm{kT}}
$$

Pada kondisi kerapatan elektron yang besar atau nilai $\mathrm{N}_{\mathrm{e}}$ sangat besar maka nilai $\mathrm{N}_{\mathrm{e}}\left(\left(\sigma_{10}^{\prime} v^{\prime}\right)\right.$ jauh lebih besar dari pada $\mathrm{A}_{10}$ maka Persamaan 2 dan 3 dapat disederhanakan menjadi Persamaan Boltzman sebagai berikut.

$$
\frac{\mathrm{N}_{1}^{*}}{\mathrm{~N}_{0}}=\frac{\mathrm{gr}_{\mathrm{I}}}{\mathrm{gr}_{0}} \mathrm{e}^{-\mathrm{E}_{\mathrm{r}} / \mathrm{kT}}
$$

Sebaliknya, bila kerapatan elektron kecil yang berarti $\mathrm{N}_{\mathrm{e}}$ kecil, maka nilai $\mathrm{N}_{\mathrm{e}}\left(\left(\sigma_{10}^{\prime} v^{\prime}\right)\right.$ kecil dari pada $\mathrm{A}_{10}$ maka Persamaan 2 dan 3 dapat disederhanakan menjadi sebagai berikut.

$$
\frac{N_{1}^{*}}{N_{0}}=\frac{\left(\sigma_{01}\right)}{A_{10}} N_{e}
$$

maka :

$$
\frac{\mathrm{N}_{1}^{*}}{\mathrm{~N}_{0}}=\frac{1}{\mathrm{R} / \mathrm{N}_{\mathrm{e}}} \frac{\mathrm{gr}_{1}}{\mathrm{gr}_{0}} \mathrm{~A}_{10} \mathrm{e}^{-\mathrm{E}_{\mathrm{r}} / \mathrm{kT}}
$$

Nilai $\mathrm{N}_{\mathrm{e}} \geq 10^{15} \mathrm{~cm}^{-3}$ berlaku untuk Persamaan Boltzman dan nilai $\mathrm{N}_{\mathrm{e}} \leq 10^{13} \mathrm{~cm}^{-3}$ untuk kondisi coronal model pada Persamaan 9. Rumus pendekatan yang dapat digunakan untuk memperoleh jumlah atom tereksitasi $\mathrm{N}_{1}^{*}$ dapat ditulis sebagai berikut.

$$
\mathrm{R}=10^{13} \mathrm{E}_{\mathrm{r}}^{3} \mathrm{~T}_{\mathrm{e}}^{1 / 2}
$$

Dengan mengetahui nilai $R$, maka penampang elementer $(\sigma)$ dapat ditentukan. Jika nilai penampang elementer dan koefisien Einstein, A, diketahui, maka nilai $\mathrm{N}_{1}^{*}$ dapat ditentukan. 
Di dalam praktek analisis spektrografi emisi, nilai $\mathrm{E}_{\mathrm{T}}$ berkisar antara 3-15 ev, $\mathrm{T}_{\mathrm{e}}$ berkisar antara $0,5-4 \mathrm{ev}$ dan dalam plasma spark $\mathrm{N}_{\mathrm{c}}$ berkisar a $10^{17} \mathrm{~cm}^{-3}$, sedangkan di dalam arc $\mathrm{N}_{\mathrm{c}}$ berkisar antara $10^{14}-10^{15} \mathrm{~cm}^{-3}[3]$.

Pada tahapan proses $\mathrm{N}_{1}^{*} \rightarrow \mathrm{I}$, jika $\mathrm{N}_{0}$ merupakan konsentrasi atom dalam sumber eksitasi, I sebagai intensitas garis spektrum atom, dan h sebagai tetapan Planck, maka intensitas garis spektrum dapat ditulis dengan persamaan sebagai berikut.

$$
\mathrm{I}=\frac{\mathrm{hv}}{4 \pi} \frac{1}{1+\mathrm{R} / \mathrm{N}_{\mathrm{e}}} \frac{\mathrm{gr}_{1}}{\mathrm{gr}_{0}} \mathrm{~N}_{0} \mathrm{e}^{-\mathrm{E}_{\mathrm{r}} / \mathrm{kT} \mathrm{T}_{\mathrm{e}}}
$$

Dari Persamaan 11 dapat disimpulkan bahwa intensitas garis spektrum sebanding dengan konsentrasi atom di dalam sumber eksitasi, $\mathrm{N}_{0}$. Adanya faktor

$\mathrm{e}^{-E_{1} / \mathrm{T}_{\mathrm{e}}}$ menunjukkan bahwa intensitas garis spektrum dipengaruhi oleh temperatur plasma $T_{e}$. Dengan menggunakan parameter sumber eksitasi yang divariasi misalnya arus pada sumber eksitasi arc atau variasi kapasitas, induktan, atau resitan pada sumber eksitasi spark akan diperoleh variasi intensitas garis spektrum. Variasi temperatur biasanya disertai dengan variasi konsentrasi elektron di dalam sistem eksitasi, sehingga intensitas garis spektrum dipengaruhi oleh konsentrasi elektron.

Hubungan antara intensitas garis spektrum (I) dengan jumlah atom $(\mathrm{N})$ di dalam sumber eksitasi dapat ditulis dengan persamaan pendekatan sebagai berikut.

$$
\log \mathrm{I}=\mathrm{b}_{1} \log \mathrm{N}_{\mathrm{o}}+\mathrm{a}_{1}
$$

$b_{1} \leq 1$; pada variasi konsentrasi tertentu nilai $b_{1}$ dan $a_{1}$ adalah konstanta.

Pada proses perpindahan atom dari cuplikan ke keadaan fase gas, jumlah atom yang masuk ke daerah eksitasi per satuan waktu sebanding dengan konsentrasi atom dalam cuplikan, yaitu sama dengan $\sigma \mathrm{C}$ dan jumlah atom yang keluar dari daerah eksitasi per satuan waktu sebanding dengan konsentrasi di dalam sumber eksitasi, yaitu $\beta \mathrm{N}_{0}$. Kecepatan perpindahan atom di dalam sumber eksitasi adalah:

$$
\frac{\mathrm{dN}_{0}}{\mathrm{dt}}=\alpha \mathrm{C}-\beta \mathrm{N}_{0}
$$

Dalam keadaan stasioner kecepatan perpindahan atom ini sama dengan 0 , sehingga:

$$
\alpha \mathrm{C}=\beta \mathrm{N}_{0} \quad \text { atau } \quad \mathrm{N}_{0}=\frac{\alpha}{\beta} \mathrm{C}
$$


Berdasarkan Persamaan 13 dan 14 diperoleh rumus Scheibe-Lomakin sebagai berikut,

$$
\log \mathrm{I}=\mathrm{b} \log \mathrm{C}+\mathrm{a}
$$

dengan :

I $=$ intensitas

$\mathrm{a}$ dan $\mathrm{b}=$ tetapan

$\mathrm{C}=$ konsentrasi unsur yang ditentukan

Persamaan 15 merupakan dasar analisis kuantitatif dengan metode spektrografi emisi, konsentrasi cuplikan ditentukan berdasarkan pengukuran intensitas garis spektrum unsur secara komparatif yaitu dengan menggunakan standar (pembanding) ${ }^{[6]}$.

Persamaan reaksi yang terjadi antara $\mathrm{U}_{3} \mathrm{O}_{8}$ dengan pengemban secara umum dapat dinyatakan sebagai berikut :

$$
A+B \rightarrow R
$$

dengan :

$\mathrm{A}=$ boron atau kadmium dalam $\mathrm{U}_{3} \mathrm{O}_{8}$

$\mathrm{B}=$ pengemban (campuran $\mathrm{Ga}_{2} \mathrm{O}_{3}, \mathrm{AgCl}$, dan $\mathrm{LiF}$ )

$\mathrm{R}=$ hasil reaksi

Secara umum persamaan kecepatan reaksi dapat ditulis dengan ${ }^{[7,8]}$.

$$
\mathrm{r}_{\mathrm{N}}=-\mathrm{dC}_{\mathrm{N}} / \mathrm{dt}=\mathrm{kC}_{\mathrm{N}^{\mathrm{n}}}
$$

dengan :

$\mathrm{r}_{\mathrm{N}}=$ kecepatan eksitasi unsur $\mathrm{N}$

$\mathrm{C}_{\mathrm{N}}=$ konsentrasi unsur $\mathrm{N}$

$\mathrm{t}=$ waktu

$\mathrm{k}=$ konstanta kecepatan reaksi, dan $\mathrm{n}$ orde reaksi.

Persamaan 17 dapat dibuat linier menjadi :

$$
\log \mathrm{r}_{\mathrm{N}}=\log \left(-\mathrm{dC}_{\mathrm{N}} / \mathrm{dt}\right)=\log \mathrm{k}+\mathrm{n} \log \mathrm{C}_{\mathrm{N}}
$$

Untuk menganalisis data yang diperoleh dapat menggunakan metode diferensial maupun metode integral. Metode memerlukan hubungan konsentrasi dengan waktu. Hal ini dilakukan dengan cara melakukan variasi waktu eksitasi. Konsentrasi awal unsur tak murnian adalah sama dengan kadar maksismum yang terdeteksi yang diperoleh dalam waktu optimum. Konsentrasi yang terdeteksi dari beberapa waktu eksitasi yang lebih pendek dari waktu optimumnya selalu lebih rendah dari konsentrasi maksimum ini. Selisih konsentrasi maksimum 
dengan konsentrasi yang terdeteksi merupakan sisa unsur yang tidak tereksitasi. Dari kurva konsentrsasi dengan waktu dilakukan analisis dengan metode diferensial untuk memperoleh orde dan konstanta kecepatan reaksi. Langkahlangkah yang harus diikuti, adalah sebagai berikut ${ }^{[8]}$ :

1. Menggambar grafik smooth hubungan konsentrasi $\left(\mathrm{C}_{\mathrm{A}}\right)$ dan waktu $(\mathrm{t})$, kemudian ditentukan slope dari kurva yang telah dibuat pada beberapa nilai konsentrasi. Slope $\frac{\mathrm{dC}_{\mathrm{A}}}{\mathrm{dt}}=\mathrm{r}_{\mathrm{A}}$ adalah laju reaksi pada komposisi ini.

2. Untuk mendapatkan persamaan reaksi maka dibuat grafik $\log \left(-\mathrm{dC}_{\mathrm{A}} / \mathrm{dt}\right)$ dengan $\log \mathrm{C}_{\mathrm{A}}$.

Dengan mengikuti hubungan konsentrasi dengan waktu maka dapat diketahui persamaan kecepatan reaksi yang diinginkan sehingga nilai $\mathrm{k}$ dan $\mathrm{n}$ dapat diperoleh.

Jika reaksi yang terjadi mengikuti reaksi orde satu, maka Persamaan 17 dapat ditulis menjadi:

$$
\mathrm{r}_{\mathrm{N}}=-\mathrm{dC}_{\mathrm{N}} / \mathrm{dt}=\mathrm{kC}_{\mathrm{N}}
$$

Penyusunan kembali dan integrasi dalam batas $\mathrm{C}=\mathrm{C}_{0}$ sampai $\mathrm{C}=\mathrm{C}_{1}$ dan waktu $\mathrm{t}=0$ sampai dengan $\mathrm{t}=\mathrm{t}$ menghasilkan persamaan sebagai berikut.

$$
-\ln \frac{\mathrm{C}_{\mathrm{A}}}{\mathrm{C}_{\mathrm{A} 0}}=\mathrm{kt}
$$

Berdasarkan Persamaan 20 dapat ditentukan nilai k.

Dalam analisis ini diperlukan penambahan pengemban (carrier) dalam cuplikan. Analisis dengan cara spektrografi emisi umumnya dilakukan dengan penambahan pengemban untuk membantu penguapan unsur pengotor di dalam proses eksitasi sehingga mempercepat pembentukan spektrum unsur pengotor dan menghambat pembentukan spektrum matriks. Umumnya senyawa yang digunakan sebagai pengemban adalah senyawa halida atau campuran senyawa halida oksida. Pengemban-pengemban yang biasa digunakan adalah $\mathrm{Ga}_{2} \mathrm{O}_{3}, \mathrm{LiF}$, dan $\mathrm{AgCl}$. Standar $\mathrm{U}_{3} \mathrm{O}_{8}$ yang digunakan adalah SRM (Standard Reference Materials).

Serbuk uranium oksida $\left(\mathrm{UO}_{2}\right)$ merupakan salah satu bahan baku untuk pembuatan elemen bakar nuklir. Sebelum digunakan sebagai bahan baku untuk pembuatan elemen bakar nuklir, serbuk $\mathrm{UO}_{2}$ tersebut harus memenuhi salah satu syarat yaitu bebas atau sedikit sekali mengandung unsur takmurnian (impurities) karena dapat mengurangi efektifitas reaksi uranium dengan neutron di dalam reaktor nuklir. Unsur-unsur yang dapat mengurangi efektifitas ini adalah unsur-unsur yang mempunyai 
penampang lintang serapan neutron yang besar seperti boron (B), kadmium (Cd), dan unsur-unsur tanah jarang. Oleh karena itu, $\mathrm{UO}_{2}$ harus diuji terlebih dahulu kemurniannya sebelum digunakan sebagai bahan bakar reaktor nuklir ${ }^{[9,10]}$.

Persamaan kecepatan reaksi yang diperoleh dapat dimanfaatkan untuk menentukan waktu paparan yang tepat sehingga diperoleh data yang valid.

Dari konstanta kecepatan reaksi yang diperoleh digunakan untuk menghitung waktu yang diperlukan agar semua terkesitasi dan dapat didekati dengan umur rata-rata disistegrasi zat radiokatif karena sama-sama memiliki reaksi orde satu, maka umurnya dapat ditulis dengan Persamaan $21^{[11]}$.

$$
\tau=\frac{-\int_{\infty}^{0} \lambda \mathrm{tN}_{0} \mathrm{e}^{-\lambda t} \mathrm{dt}}{\mathrm{N}_{0}}=\frac{1}{\lambda}
$$

Persamaan ini dapat digunakan untuk waktu eksitasi, dalam hal ini $\lambda$ ekivalen dengan konstanta kecepetan reaksi orde 1.

\title{
METODE PENELITIAN
}

\section{Bahan}

Bahan-bahan yang digunakan adalah uranium oksida $\left(\mathrm{UO}_{2}\right), \mathrm{U}_{3} \mathrm{O}_{8} \mathrm{SRM}$, asam format $(\mathrm{HCOOH})$ Merck, asam nitrat $3 \mathrm{~N}$ Merck, aquadest, alkohol Merck, pengemban $\left(\mathrm{Ga}_{2} \mathrm{O}_{3}, \mathrm{LiF}\right.$, dan $\left.\mathrm{AgCl}\right)$ Spex Industry, Kodak Developer D 19, dan Kodak Rapid Fixer.

\begin{abstract}
Alat
Alat-alat yang digunakan adalah seperangkat alat kalsinasi, pengaduk, kaca arloji, cawan porselin, gelas beker $100 \mathrm{ml}$, gelas ukur $50 \mathrm{ml}$, labu takar $25 \mathrm{ml}$ dan $5 \mathrm{ml}$, kompor listrik, unit analiser Spektrografi Emisi, densitometer, film, timbangan analog Sartorius 2405 , dan penggerus porselin.

\section{Cara Kerja}

Cuplikan dibuat dari uranium dioksida $\left(\mathrm{UO}_{2}\right)$ ditambah asam nitrat $\left(\mathrm{HNO}_{3}\right)$ sampai larut sehigga diperoleh larutan uranil nitrat $\left(\mathrm{UO}_{2}\left(\mathrm{NO}_{3}\right)_{2}\right)$. Larutan uranil nitrat ini dipanaskan sampai mendekati kering, lalu ditambah asam format $(\mathrm{HCOOH})$ tetes demi tetes sampai larut sehingga diperoleh larutan uranil format $\left(\mathrm{UO}_{2}(\mathrm{COOH})_{2}\right)$. Uranil format diuapkan dan dikalsinasi dengan suhu $850{ }^{\circ} \mathrm{C}$ selama 3 jam. Setelah itu dicampur pengemban sulingan sebanyak 2,5\% menggunakan penggerus porselen. Pengemban sulingan yang digunakan adalah campuran dari $\mathrm{AgCl}, \mathrm{Ga}_{2} \mathrm{O}_{3}$, dan $\mathrm{LiF}$ dengan perbandingan 95:1:4. Cuplikan yang berbentuk serbuk ini ditimbang sebanyak $100 \mathrm{mg}$ untuk diukur transmitansinya menggunakan spektrografi emisi. Untuk menentukan jumlah
\end{abstract}


pengemban yang baik dilakukan variasi pengemban sebanyak $5 \%, 7,5 \%$, dan $10 \%$.

Standar dibuat dengan $\mathrm{U}_{3} \mathrm{O}_{8}$ SRM yang sudah ditambahkan dengan pengemban. Konsentrasi boron dan kadmium pada masing-masing standar sudah diketahui. Masing-masing seri standar ditimbang $100 \mathrm{mg}$ untuk dieksitasikan.

Cuplikan dan standar masing-masing dimasukkan ke dalam elektroda grafit kemudian dieksitasi untuk mendapatkan data transmitansi. Kondisi eksitasi adalah sebagai berikut :
a. Grating
90 groves $/ \mathrm{mm}$
b. Sumber arus
C-Arc
c. Pre-burn
detik
d. Exposure
5 detik
e. Arus
0 amper
f. Jarak elektroda : $2 \mathrm{~mm}$
g. Tinggi spektrum : $2 \mathrm{~mm}$

Di samping itu juga dilakukan proses eksitasi dengan waktu paparan yang berbeda dan dilakukan proses eksitasi untuk cuplikan $5 \%$ pengemban dengan memvariasikan waktu $5,10,15,20,25,30$, dan 35 detik.

Hasil eksitasi dalam pelat film dapat dilihat dengan mencuci pelat film, dengan cara merendam pelat film dalam developer selama 5 menit, kemudian direndam dalam fixer selama 5 menit, lalu dicuci dengan air mengalir selama kurang lebih 5 menit, lalu dikeringkan.

Analisis kualitatif dan kuantitatif dlakukan dengan alat densitometer. Analisis kualitatif berdasarkan pada spektrum standar $\mathrm{Fe}$ di berbagai panjang gelombang sedangkan analisis kuantitatifnya berdasarkan pada densitas atau persen transmitansi dari masing-masing spektrum unsur yang dianalisis dibandingkan dengan persen transmitansi standar.

\section{HASIL DAN PEMBAHASAN}

Bahan bakar uranium oksida $\left(\mathrm{UO}_{2}\right)$ yang digunakan sebagai cuplikan harus diubah terlebih dahulu ke dalam bentuk oksida yang lebih stabil pada suhu tinggi. Senyawa $\mathrm{UO}_{2}$ jika dipanaskan akan bereaksi dengan oksigen di udara dan menghasilkan $\mathrm{UO}_{3}$ atau $\mathrm{U}_{3} \mathrm{O}_{8}$. Oleh karena itu, sebelum $\mathrm{UO}_{2}$ digunakan sebagai cuplikan maka $\mathrm{UO}_{2}$ harus dikalsinasi terlebih dahulu menjadi $\mathrm{U}_{3} \mathrm{O}_{8}$ yang stabil pada suhu tinggi agar pada sistem eksitasi unsur takmurnian yang terdapat pada cuplikan dapat tereksitasi dengan baik. Jika cuplikan dalam bentuk $\mathrm{UO}_{2}$ yang mengandung unsur takmurnian langsung dieksitasikan, maka unsur takmurnian yang terdapat dalam cuplikan akan tereksitasi sebagian dan sisanya akan terganggu karena pengaruh perubahan matriks $\mathrm{UO}_{2}$ yang tidak stabil pada suhu tinggi. Gangguan yang terjadi selama eksitasi akan berakibat pada jumlah unsur 
takmurnian yang tereksitasi dan akhirnya akan berakibat pada jumlah intensitas masing-masing unsur takmurnian yang terdeteksi pada pelat film yang berfungsi sebagai detektor. Selain itu, metode spektrografi emisi memerlukan suatu standar yaitu $\mathrm{U}_{3} \mathrm{O}_{8}$ SRM (Standard Reference Materials) maka cuplikan yang akan dianalisis diusahakan sama dengan matriks standar sehingga diharapkan sifat eksitasi $\mathrm{U}_{3} \mathrm{O}_{8}$ tidak jauh berbeda dengan standarnya. waktu exposure (paparan) pada saat cuplikan dieksitasi.

Konsentrasi pengemban yang baik ditentukan dengan percobaan variasi pengemban $\mathrm{AgCl}, \mathrm{Ga}_{2} \mathrm{O}_{3}$, dan $\mathrm{LiF}$ yang ditambahkan ke dalam cuplikan $\mathrm{U}_{3} \mathrm{O}_{8}$ dengan waktu exposure (paparan) 15, 25, dan 35 detik. Dari hasil penelitian yang diperoleh menunjukkan bahwa semakin banyak pengemban yang ditambahkan maka intensitas yang diperoleh semakin besar. Hal ini disebabkan semakin banyak bahan yang dapat mengakumulasi unsur takmurnian di dalam cuplikan sehingga unsur takmurnian dapat tereksitasi sebanyak-banyaknya. Selain itu, intensitas yang semakin besar tersebut menunjukkan fungsi pengemban sebagai bahan yang dapat meningkatkan sensitifitas sehingga intensitas yang terbaca semakin besar. Dari percobaan dapat diketahui bahwa hasil analisis terbaik digunakan konsentrasi pengemban $5 \%$. Untuk itulah pada variasi waktu exposure (paparan), pengemban yang ditambahkan ke dalam cuplikan adalah $5 \%$.

Hasil eksitasi $\mathrm{U}_{3} \mathrm{O}_{8}$ SRM adalah transmitansi dari masing-masing $\mathrm{U}_{3} \mathrm{O}_{8}$ SRM yang kemudian dikonversikan menjadi intensitas dengan rumus $\mathrm{D}=\log 1 / \mathrm{T}$. Intensitas yang didapatkan kemudian dihubungkan dengan konsentrasi $\mathrm{U}_{3} \mathrm{O}_{8}$ SRM sehingga menghasilkan kurva kalibrasi standar antara konsentrasi sebagai $\mathrm{x}$ dan intensitas sebagai y menjadi garis regresi seperti ditunjukkan dengan Persamaan 15 diperoleh dari kurva kalibrasi tersebut. Persamaan garis untuk boron adalah $\mathrm{y}=0.0913 \mathrm{x}+$ 0.0398 . Persamaan garis untuk kadmium adalah $\mathrm{y}=0.0125 \mathrm{x}+0.0512$. Persamaan garis regresi inilah yang digunakan untuk menghitung konsentrasi cuplikan karena sudah memenuhi uji korelasi dengan nilai $\mathrm{r}$ yang signifikan dan linier. Nilai intensitas dari tiap-tiap cuplikan disubsitusikan pada nilai y dari persamaan dan diperoleh nilai $\mathrm{x}$ sebagai konsentrasi. Konsentrasi pada tiap-tiap cuplikan inilah yang digunakan untuk menentukan persamaan kecepatan reaksi yang terjadi selama proses eksitasi. Nilai konsentasi pada setiap cuplikan dapat dilihat pada Tabel 1 untuk boron dan Tabel 2 untuk kadmium. 
Tabel 1. Konsentrasi Cuplikan Boron pada Setiap Variasi Waktu

\begin{tabular}{ccccc}
\hline Waktu $(\mathrm{s})$ & Transmitansi (\%) & Intensitas (I) & $\mathrm{C}(\mathrm{ppm})$ & $\mathrm{C}_{\mathrm{A}}(\mathrm{ppm})$ \\
\hline 5 & 79.9 & 0.09745 & 0.63135 & 2.50484 \\
10 & 66 & 0.18045 & 1.54077 & 1.59542 \\
15 & 58.5 & 0.23284 & 2.11479 & 1.0214 \\
20 & 55 & 0.25964 & 2.40844 & 0.72775 \\
25 & 53.7 & 0.27002 & 2.52217 & 0.61402 \\
30 & 52.9 & 0.27654 & 2.59361 & 0.54258 \\
35 & 49.2 & 0.30803 & 3.13619 & 0 \\
\hline
\end{tabular}

Tabel 2. Konsentrasi Cuplikan Kadmium pada Setiap Variasi Waktu

\begin{tabular}{ccccc}
\hline Waktu $(\mathrm{s})$ & Transmitansi (\%) & Intensitas (I) & $\mathrm{C}(\mathrm{ppm})$ & $\mathrm{C}_{\mathrm{A}}(\mathrm{ppm})$ \\
\hline 5 & 88.8 & 0.05159 & 0.76347 & 1.36505 \\
10 & 85.3 & 0.06905 & 1.10449 & 1.02403 \\
15 & 82.1 & 0.08566 & 1.42891 & 0.69961 \\
20 & 80.7 & 0.09312 & 1.57461 & 0.55391 \\
25 & 78.5 & 0.10513 & 1.80918 & 0.31934 \\
30 & 77.5 & 0.11069 & 1.91777 & 0.21075 \\
35 & 75.6 & 0.12148 & 2.12852 & 0 \\
\hline
\end{tabular}

Dari yang ditampilkan pada Tabel 1 dan 3, C adalah konsentrasi yang terukur atau dapat dikatakan menunjukkan unsur yang dapat tereksitasi, sedangkan $\mathrm{C}_{\mathrm{A}}$ adalah konsentrasi unsur yang masih terdapat dalam cuplikan. Semakin lama waktu exposure (paparan) maka konsentrasi yang didapatkan akan semakin besa dan unsur yang tertinggal dalam cuplikan semakin sedikit. Hal ini disebabkan kesempatan zat-zat untuk tereksitasi semakin besar dengan bertambahnya waktu . Ini juga menunjukkan bahwa semakin lama waktu paparan atom yang tereksitasi juga semakin banyak.

Untuk mendapatkan persamaan kecepatan reaksi pertama dilakukan pengecekekan orde reaksi menggunakan metode diferensial. Metode analisis diferensial berhubungan langsung dengan persamaan laju/kecepatan diferensial yang akan diuji. Pada metode ini, konsentrasi yang didapatkan kemudian dihubungkan dengan waktu sehingga diperoleh suatu kurva dimana antara garis yang satu dengan yang lain dihubungkan dan dibuat suatu garis yang smooth.

Konsentrasi yang digunakan untuk perhitungan persamaan kecepatan reaksi berasal dari konsentrasi yang didapat pada saat waktu 35 detik dikurangi konsentrasi pada setiap variasi waktu. Hasil perhitungan yang diperoleh dapat dilihat pada Gambar 3 . 


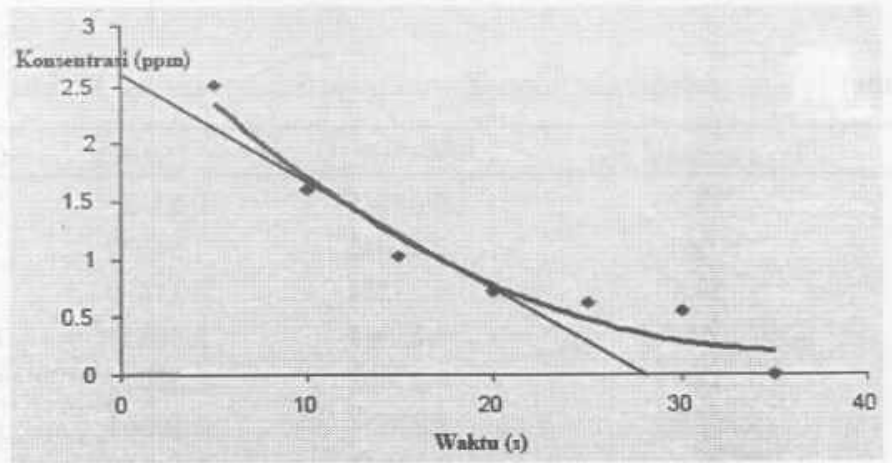

Gambar 3. Kurva Hubungan Konsentrasi Boron dengan Waktu

Dari kurva seperti Gambar 3 diambil beberapa titik konsentrasi dan waktu kemudian ditentukan slope pada garis singgung titik-titik yang dipilih. Slope $\mathrm{dC}_{\mathrm{A}} / \mathrm{dt}=\mathrm{r}_{\mathrm{A}}$ adalah laju reaksi pada komposisi ini. Untuk mendapatkan persamaan kecepatan reaksi maka sesuai dengan Persamaan 18 dibuat grafik $\log \left(-\mathrm{dC} \mathrm{C}_{\mathrm{A}} / \mathrm{dt}\right)$ dengan $\log \mathrm{C}_{\mathrm{A}}$. Hasil yang diperoleh dapat dilihat pada Tabel 3 dan Gambar 4 untuk boron dan Tabel 4 dan Gambar 5 untuk kadmium.

Tabel 3. Konsentrasi Cuplikan Boron pada Setiap Variasi Waktu

\begin{tabular}{lllll}
\hline Waktu (s) & \multicolumn{1}{c}{$\mathrm{C}_{\mathrm{A}}$} & \multicolumn{1}{c}{$\mathrm{dC}_{\mathrm{A}} / \mathrm{dt}$} & $\log \left(-\mathrm{dC}_{\mathrm{A}} / \mathrm{dt}\right)$ & $\log \mathrm{C}_{\mathrm{A}}$ \\
\hline 0 & 3,1 & & & \\
5 & 2.5 & -0.18378 & -0.7357 & 0.39794 \\
7.5 & 2.25 & -0.17631 & -0.75372 & 0.35128 \\
10 & 1.6 & -0.13563 & -0.86764 & 0.20412 \\
12.5 & 1.325 & -0.12222 & -0.91286 & 0.12222 \\
15 & 1 & -0.09134 & -1.03934 & 0 \\
17.5 & 0.825 & -0.06779 & -1.16883 & -0.08355 \\
20 & 0.675 & -0.0576 & -1.23958 & -0.17069 \\
22.5 & 0.525 & -0.04851 & -1.31417 & -0.27984 \\
25 & 0.45 & -0.04485 & -1.34824 & -0.34679 \\
27.5 & 0.325 & -0.04286 & -1.36795 & -0.48812 \\
\hline
\end{tabular}

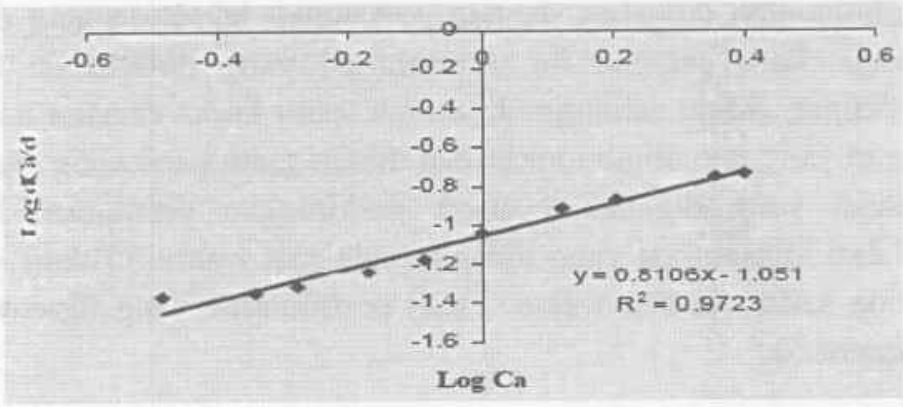

Gambar 4. Kurva Hubungan $\log \mathrm{dC}_{\mathrm{A}} / \mathrm{dt}$ dengan $\log \mathrm{C}_{\mathrm{A}}$ untuk Cuplikan Boron. 
Dari kurva hubungan $\log \mathrm{dC}_{\mathrm{A}} / \mathrm{dt}$ dengan $\log \mathrm{C}_{\mathrm{A}}$ untuk cuplikan boron tersebut didapatkan persamaan kecepatan reaksinya yaitu :

$$
-r_{B}=-\frac{d_{B}}{d t}=0.089 C_{A}^{0.81} \frac{\mathrm{mg}}{\mathrm{g} \cdot \mathrm{s}} \text {. }
$$

Tabel 4. Konsentrasi Cuplikan Kadmium pada Setiap Variasi Waktu

\begin{tabular}{lllll}
\hline Waktu $(\mathrm{s})$ & $\mathrm{C}_{\mathrm{A}}$ & $\mathrm{dC}_{\mathrm{A}} / \mathrm{dt}$ & $\log \left(-\mathrm{dC}_{\mathrm{A}} / \mathrm{dt}\right)$ & $\log \mathrm{C}_{\mathrm{A}}$ \\
\hline 5 & 1.36 & -0.07778 & -1.10913 & 0.13354 \\
7.5 & 1.18 & -0.06939 & -1.1587 & 0.07188 \\
10 & 1 & -0.06269 & -1.2028 & 0 \\
12.5 & 0.85 & -0.05926 & -1.22724 & -0.07058 \\
15 & 0.7 & -0.05 & -1.30103 & -0.1549 \\
17.5 & 0.58 & -0.04094 & -1.38785 & -0.23657 \\
20 & 0.55 & -0.03609 & -1.44261 & -0.25964 \\
22.5 & 0.4 & -0.03188 & -1.49648 & -0.39794 \\
25 & 0.32 & -0.02943 & -1.53121 & -0.49485 \\
27.5 & 0.23 & -0.02286 & -1.64098 & -0.63827 \\
\hline
\end{tabular}

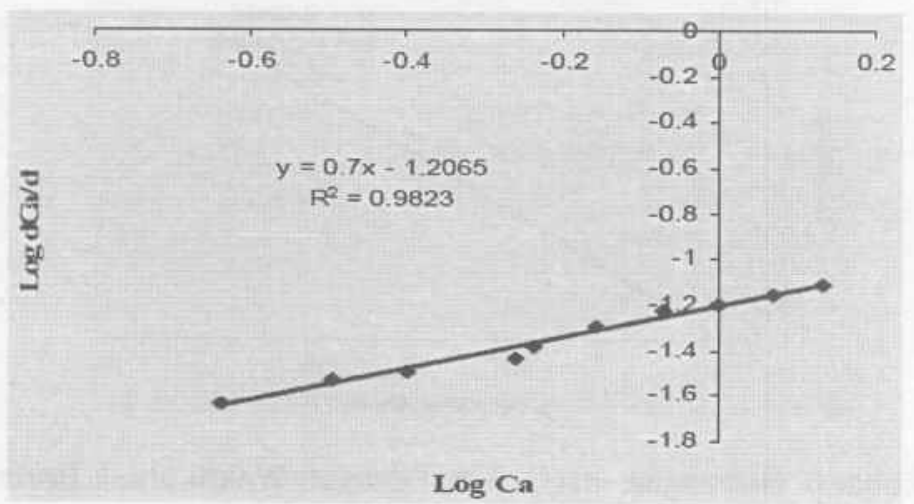

Gambar 5. Kurva Hubungan $\log \mathrm{dC}_{\mathrm{A}} / \mathrm{dt}$ dengan $\log \mathrm{C}_{\mathrm{A}}$ untuk Cuplikan Kadmium.

Dari kurva hubungan $\log \mathrm{dC}_{\mathrm{A}} / \mathrm{dt}$ dengan $\log \mathrm{C}_{\mathrm{A}}$ untuk cuplikan kadmium tersebut didapatkan persamaan kecepatan reaksinya yaitu :

$$
-\mathrm{r}_{\mathrm{Cd}}=-\frac{\mathrm{dC}_{\mathrm{Cd}}}{\mathrm{dt}}=0.062 \mathrm{C}_{\mathrm{A}}^{0.7} \frac{\mathrm{mg}}{\mathrm{g} \cdot \mathrm{s}} \text {. }
$$

Dari hasil perhitungan yang telah dilakukan dengan menggunakan metode diferensial didapatkan persamaan kecepatan reaksi untuk boron seperti Persamaan 21 dan persamaan kecepatan reaksi untuk kadmium seperti Persamaan 22. 
Dari kurva konsentrasi dengan waktu yang digunakan untuk menghitung persamaan kecepatan reaksi dapat dilihat bahwa tidak semua titik berada pada garis smooth. Hal ini dapat disebabkan kurang homogennya cuplikan dengan pengemban meskipun sudah diusahakan dicampur dengan cara manual dan memakan waktu yang cukup lama karena pencampuran unsur dalam bentuk padatan memang lebih sulit bila dibandingkan dengan bentuk cair. Disamping itu, jumlah cuplikan yang sangat terbatas yang dapat dimasukkan ke dalam anoda sebagai wadah cuplikan mungkin menjadi salah satu penyebab eksitasi unsur takmurnian menjadi kurang maksimal.

Persamaan kecepatan reaksi yang didapatkan tersebut dapat dikatakan mengikuti reaksi orde 1 yaitu reaksi-reaksi berbanding langsung dengan konsentrasi walaupun orde reaksi yang didapatkan untuk boron adalah 0,81 dan untuk kadmium adalah 0,7 yang nilainya dekat dengan 1 . Reaksi orde 1 ini dapat dievaluasi lebih lanjut dengan menggunakan metode integral, yaitu dengan membuat kurva hubungan - $\mathrm{h}$ ! $\left(\mathrm{C}_{\mathrm{A}} / \mathrm{CA}_{0}\right)$ dengan waktu sehingga diperoleh Gambar 6 untuk oron dan Gambar 7 untuk Cadmium, didasarkan pada Persamaan 20

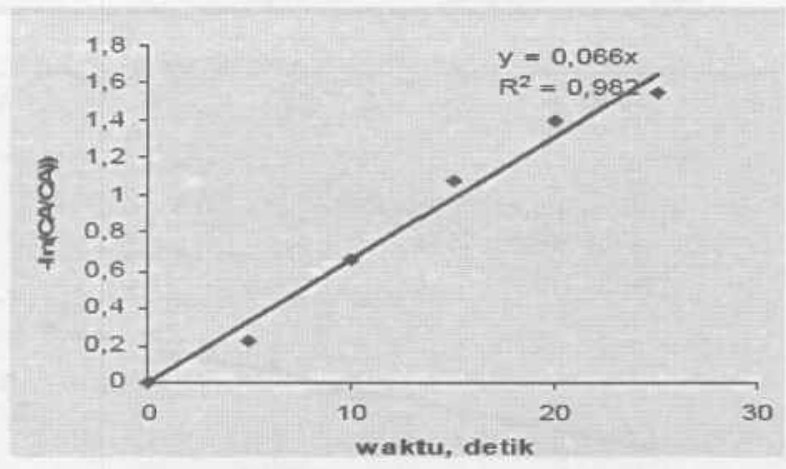

Gambar 6. Hubungan - $\ln \left(\mathrm{C}_{\mathrm{A}} / \mathrm{CA}_{0}\right)$ dengan Waktu untuk Boron

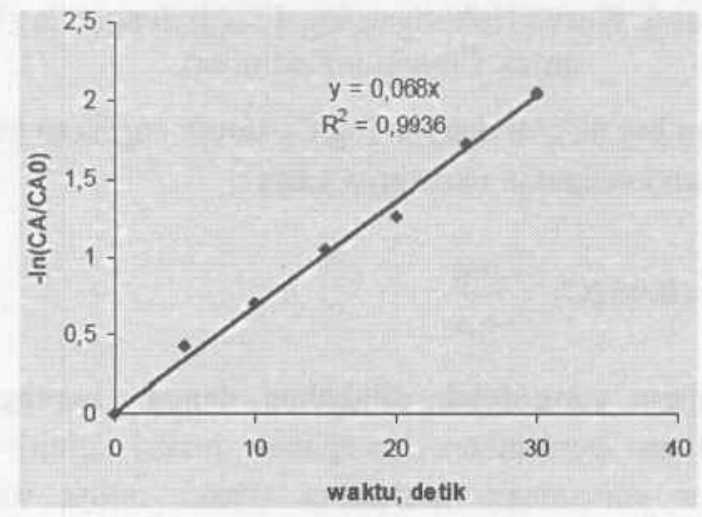

Gambar 7. Hubungan - $\ln \left(\mathrm{C}_{\mathrm{A}} / \mathrm{CA}_{0}\right)$ dengan waktu untuk $\mathrm{Cd}$ 
Dari kedua gambar di atas diperoleh konstanta kecepatan reaksi untuk boron 0,066 dan untuk Cadmium 0,068 sehingga persamaan kecepatan reaksi untuk boron dan untuk Cadmium berturut-turut dapat ditulis sebagai berikut.

$$
-r_{B}=-\frac{d_{B}}{d t}=0,066 C_{A}{ }^{\prime} \frac{m g}{g \cdot s}
$$

Persamaan kecepatan reaksi untuk kadmium dari Persamaan 22 menjadi :

$$
-r_{C d}=-\frac{d C_{C d}}{d t}=0,068 C_{A}{ }^{\prime} \frac{m g}{g \cdot s}
$$

Persamaan kecepatan reaksi ini dapat digunakan sebagai tambahan informasi untuk meningkatkan kualitas atau memperbaiki metode analisis boron dan kadmium dalam $\mathrm{U}_{3} \mathrm{O}_{8}$ dengan cara menghitung waktu yang dibutuhkan untuk mengeksitasi seluruh bahan yang terdapat dalam cuplikan.

\section{KESIMPULAN}

Dari hasil penelitian yang diperoleh, maka dapat ditarik kesimpulan sebagai berikut :

1. Semakin banyak pengemban yang ditambahkan maka intensitas yang diperoleh semakin besar dan didapatkan pengemban yang paling baik adalah $5 \%$.

2. Semakin lama waktu exposure (paparan), yaitu hingga waktu 35 detik maka konsentrasi yang didapatkan akan semakin besar.

3. Persamaan kecepatan reaksi yang terjadi pada boron yaitu

$$
-\mathrm{r}_{\mathrm{B}}=-\frac{\mathrm{dC}_{\mathrm{B}}}{\mathrm{dt}}=0,066 \mathrm{C}_{\mathrm{A}}{ }^{1} \frac{\mathrm{mg}}{\mathrm{g} \cdot \mathrm{s}} \text {. }
$$

4. Persamaan kecepatan reaksi yang terjadi pada kadmium yaitu

$$
-\mathrm{r}_{\mathrm{Cd}}=-\frac{\mathrm{dC}_{\mathrm{Cd}}}{\mathrm{dt}}=0,068 \mathrm{C}_{\mathrm{A}}{ }^{1} \frac{\mathrm{mg}}{\mathrm{g} \cdot \mathrm{s}} \text {. }
$$

\section{SARAN}

Untuk memperoleh informasi yang valid perlu dilakukan penelitian berulangulang mengenai tinjauan kinetika pada penentuan unsur-unsur takmurnian dalam bahan bakar nuklir agar diperoleh persamaan kinetika reaksi dengan ketelitian dan kecermatan yang tinggi. Selain itu, dapat dilakukan penelitian mulai dari preparasi cuplikan untuk mendapatkan persamaan kinetika reaksi secara menyeluruh. 


\section{DAFTAR PUSTAKA}

1. AHRENS L. H. dan TAYLOR S. R., 1961, Spectrochemical Analysis, 2 ed., Addison-Wesley Publishing Company Inc., New York.

2. RUKIHATI, 1984, "Metoda Spektrografi Penggunaan Pengemban Sulingan pada Penentuan Dy, Eu, Gd, dan Sm dalam $\mathrm{ThO}_{2}$, Buku Penelitian Bahan Murni dan Instrumentasi”, Pusat Penelitian Bahan Murni dan Instrumentasi, Badan Tenaga Atom Nasional, Yogyakarta.

3. RUKIHATI, 1985, "Penggunaan Pengemban Sulingan pada Penentuan Dy, Eu, Gd, dan $\mathrm{Sm}$ dalam Bahan Bakar Nuklir $\mathrm{ThO}_{2}$, Secara Spektrografi Emisi", Fakultas Pascasarjana, Universitas Gadjah Mada, Yogyakarta.

4. BASETT, J, DENNEY, R.C., JEFFREY, G.H., MENDHAM, J., 1982, Vogel's Textbook of Quantitative Inorganic Analysis including Elementary Instrumental Analysis, 4 ed., The English Language Book Society and Longman, London

5. EWING, G. W., 1986, Instrumental Methods of Chemical Analysis, 3 ed., Mc Graw Hill Kagakusha, Ltd., Singapura.

6. RUKIHATI, 1986, "Diklat Keahlian Dasar Bidang Tenaga Atom : Spektrografi Emisi", PUSDIKLAT-BATAN, Jakarta,.

7. LEVENSPIEL, O., 1999, Chemical Reaction Engineering, 3 ed., John Wiley \& Sons, Inc., New York,

8. SMITH, J. M., 1981, Chemical Engineering Kinetics, 3 ed., McGraw Hill International Book Company, Tokyo.

9. SIMBOLON, S. dan ARYADI, 1998, "Penentuan Unsur Takmurnian B dan Cd di dalam $\mathrm{U}_{3} \mathrm{O}_{8}$ dengan Metoda Spektrografi Emisi”, Prosiding Pertemuan dan Presentasi Ilmiah PPNY-BATAN, Yogyakarta.

10. HABIBI, Y., 2002, "Penentuan Unsur Takmurnian Boron, Kadmium, dan Beberapa Unsur Tanah Jarang Dalam Kernel Secara Spektrografi Emisi”, Jurusan Kimia FMIPA Universitas Negeri Yogyakarta, Yogyakarta,.

11. RIDWAN, M., PRAYOTO, MARSONGKOHADI, ILJAS, J., dan DJOJOSUBROTO, H., 1978, "Pengantar Ilmu Pengetahuan dan Teknologi Nuklir", Badan Tenaga Atom Nasional, Jakarta. 